\title{
Ghana: Progress, Problematics and Limitations of the Success Story
}

\section{Reginald Herbold Green ${ }^{1}$}

\begin{abstract}
The small boy who breaks a pot goes to tell his mother
'It got broken' not 'I broke the pot' but 'It got

broken' ... and who did this? We did.

We broke the pot.
\end{abstract}

- Jerry John Rawlings,

Chairman PNDC

\section{Beginning Again - toward Work and Happiness or a New Illusion?}

The slogan of Kwame Nkrumah's Convention People's Party in the early 1960s was 'Work and Happiness for All'. The semi-illicit opposition styled its economic critique 'It Will Not Be Work and Happiness for All' and when the CPP government was withdrawn two disillusioned European radicals styled their revised perceptions 'Ghana: End of an Illusion'. Since 1983 the Ghana economy has been turned around to become the very model of a modern stabilisation and adjustment programme (IMF/World Bank variant), and the Provisional National Development Council government instituted at the end of 1981 by retired Flight Lieutenant Jerry Rawlings has come to be perceived - especially in the North - as leading Ghana at last toward work and happiness for all under the platonic guardianship and tutelage of the Fund and the Bank.

Or is this merely a new illusion? Is the undeniable 1983-87 output recovery anything but a weather fuelled clawback to the already depressed levels of the late 1970 s? Has it any real chance of continuing? Does fiscal and monetary stabilisation rest on any firmer foundation than cutting already tottering basic social service budgets and borrowing more abroad? Are even the external credits safe - much less the poor of Accra's Nima-Mamobi slum, of the peripheral northern and upper regions, let alone the infants and young children whose mortality rates seem to have begun to rise, reversing a trend of three decades? Even if it is economically sustainable, is this 'Adjustment

\footnotetext{
Professor Green has worked in and researched on Ghana periodically since 1960. From 1985 he has been involved, as a consultant to UNICEF and as a contributor to the World institute of Development Economic Research (WIDER) in a cross-country stabilisation project headed by Lance Taylor. This article is an abbreviated and updated version of the Ghana case study from the WIDER project.
}

with an Inhuman Face' - the presumptive mirror image of UNICEF's “Adjustment with a Human Face"? These questions may oversimplify - the glosses of both proponents and opponents surely do. But they are serious questions - especially for the people of Ghana, but also for the Fund and Bank whose SSA model's prestige and perhaps even credibility are on the line in Ghana. As such they deserve serious attempts at provisional, partial answers.

\section{Black Star Rising - and Setting?}

1983-87 cannot be understood without going back to the late $1950 \mathrm{~s}$ and even, perhaps, the late $1890 \mathrm{~s}$. Ghana's economic history is not particularly typical of sub-Saharan Africa, nor was its 1983 conjuncture. To view it as either is likely to impede analysis.

In the period 1890-1910 the then Gold Coast's tree crop farmers pioneered the West African cocoa industry, and from nothing turned their colony into the world's largest producer - a position Ghana held until the late 1970 s, peaking at the end of the Nkrumah period at over 400,000 tonnes representing over 40 per cent of world output. European investment in timber extraction and gold mining - plus related infrastructure - as well as in external and wholesale trade, together with the cocoa farmers, had by 1910 created the modern Ghanaian economy, and a five-year development plan in the 1920 s consolidated the physical and began building the human (hospitals, sixth form college) infrastructure.

After the prolonged depression of the late 1920s and 1930 s - continued by isolation during World War II - the Gold Coast economy experienced a renewal first of growth (within the 1910 production and 1920 s infrastructure frame) over 1947-57 and then an attempted structural adjustment focused on industry (manufacturing and hydropower). Cocoa, timber (with some processing) and gold spearheaded the 
production/export growth, the late colonial development effort (largely financed by the balances built up from exports in the war period) the growth of infrastructure. And so to independence in 1957 as West Africa's premier colony, the showpiece of Britain's Third Empire and of tutelage for responsible black leadership (not that Kwame Nkrumah and the CPP had initially been the colonial regime's chosen agents for that transition - far from it).

The Nkrumah period was marked by a rush for growth and for structural change based on high, state led productive and economic sector infrastructure and human investment, especially in education. Until 1960 the Black Star, symbol of Ghana, stood for steady rises in output, in investment, in education, in apparent mass prosperity and social welfare. There were clouds - but they then appeared to be small ones. The world cocoa boom was clearly over (thanks in large part to the explosive rise in Ghanaian production); the growth of food production had, with rapid urbanisation and unchanged peasant technology, begun to lag population growth by the middle 1950s; the high investment and recurrent statal and parastatal spending was beginning to exert external balance and (less clearly) inflationary pressures; the northern and upper regions (and adjacent districts) remained stagnant and peripheral to the economy and polity.

In 1960-61 these stresses led to a mini external and internal balance crisis, temporarily resolved by a tough budget, import and foreign exchange control and continued focusing on investing Ghana into the future. That resolution was at best transitory. Over 1961-65 world cocoa prices collapsed - as did grower prices, although the government maintained them at border parity and (by giving up cocoa's surplus generation role) sharply raised them as a percentage of export proceeds. Inflation exploded, food production lagged, per capita consumption was cut to ribbons to sustain high recurrent service and capital budgets. Discontent became omnipresent - as did its (fairly mild) repression. The productive sector investment was in part ill-designed (and corrupted) and in part delayed and unable to perform in the worsening macro climate. Output faltered. In 1966 the Ghanaian army moved and President Nkrumah was overthrown.

The first two military governments (1966-69) conducted a Bank/Fund advised stabilisation - up to a point. Private consumption was partly restored, and military spending raised; external and budgetary imbalances reduced - within a basically static out put per capita. A partial recovery in cocoa prices in 1966 helped, but the real motor for stabilisation was demand management - drastically cutting both investment and non-military government spending. The second civilian regime, whose economic architect, J. H. Mensah, had been Nkrumah's main economic planner until the early 1960 s, sought to sustain higher consumption, restore public services and return to the CPP's high investment/high growth strategy (not least by completing the investment projects in progress before the 1966 coup). With cocoa prices again collapsing, and this time paralleled by declines in grower prices absolutely and relative to border prices, and continued lags in investment payoff and food production, both domestic and external imbalances exploded and support for the government imploded. An attempted devaluation to limit imbalance and ride out the storm until cocoa prices recovered was followed by an opportunistic army coup wrapped in a pseudo populist mantle which initially gave it trade union and left support. Ironically, within a few months the cocoa price did recover into a transitory 1974 boom.

From 1973 through 1981 it is not possible to review economic policy. The crucial point is that there was no coherent policy but only a stream of inconsistent slogans, of temporary expedients and of increasingly frantic scrambling to salvage personal and narrow sub class interests out of a steadily shrinking pot. After the 1974 cocoa boom it was downhill all the way - for investment (which even in 1986 was still negative at net level using reasonable depreciation estimates), public services, personal services, personal consumption, economic balance, political credibility and public morality. Especially over 1979-81 'chopping off the backside' (routinised, generalised, hierachical corruption) became the dominant sub-mode of exchange, and survival the central concern of the vast majority of households. The hopes and expectations of 1957 indeed seemed to be a fading illusion and a distant memory of a betrayed past.

\section{The First and Second Landings of the Flight Lieutenant}

In 1979, then Flight Lieutenant Jerry Rawlings led a coup to attempt to restore probity to the armed forces and to civil society. Its anti-corruption measures were draconic; its anti-profiteering economic policy dramatic in making existing stocks more available, less expensively. It presided over a transition to an elected, purportedly populist, government which soon reversed the partial cleansing and which faced the aftermath of forced stock rundowns and price cuts with no parallel stimulation of production.

As Ghana stumbled into its worst economic crisis, characterised by horrendous imbalances, falling output, rising poverty, the opening of the century's worst three year drought, health service collapse and the return of two killer diseases (yaws and yellow fever) wiped out a quarter century before, in the dying days of 1981, the retired Flight Lieutenant returned at the head of the PNDC. This time he proposed moral, 
social, political and economic reconstruction - not a one-off cleansing and handover.

1982 saw a go-it-alone stabilisation and adjustment effort. Cocoa was given priority - higher grower prices (from perhaps 25 per cent of export proceeds and 30 per cent of border prices), prompt payment (vs 9 months delay), mobilisation of labour and the remnants of the transport system. Price controls and the anti corruption drive pushed inflation under 25 per cent (vs 50-100 per cent levels from 1975 on). The state gained credibility as having public (not merely self interested) intentions, concern for civil society, some coherent idea as to what it was doing, a capacity to organise and allocate resources to priority ends.

But it was too late for a nationally engineered turnaround. Exports and government revenue could not be raised enough to break the import and fiscal noose choking the life out of the economy, the public services and civil society. The 1973-81 record placed international credibility - and financial support out of reach; a result reinforced by the people's power rhetoric and policy of the PNDC and the implacable hostility to it of the Reagan administration.

As 1982 waned - and the drought waxed - the PNDC decided that the only way to break out of decline was to secure the external resources to restore imports to revitalise capacity, rehabilitate infrastructure, regain productive advance. And the only way to do that was to go to the IMF and World Bank on their terms, negotiating from an historic (Ghanaian) record of no performance, and a present foundation of a crumbling economy and society.

\section{Stabilisation: The Programme Evolves}

The 1983-85 Stabilisation/Adjustment programme was basically traditional or new orthodox with one exception, a deliberate immediate target to increase import capacity via increased concessional finance. The programme was based on an initial shock treatment - particularly in respect to the exchange rate - followed by sustained gradualism and supported by increasing real resource inflows over 1983-86. Its main elements were:

Devaluation - shock treatment in 1983 from Cedi 2.75 to 30 to the US $\$$ followed by a downward crawl in 1984 to Cedi 50 to the $\$$ and 60 at the end of 1985 . This was followed by a second shock devaluation to Cedi 90 to the $\$$. A third shock treatment was moving to a managed auction system in the second half of 1986 with a year end (and mid 1987) rate of 150 Cedi per $\$$ (vs a parallel rate of the order of 200).

Fiscal policy called for reducing the government borrowing requirement, initially largely by expenditure cuts when government spending was under 10 per cent of GDP and the borrowing requirement under three per cent.
Monetary policy was designed to hold domestic credit formation below 20 per cent (largely by reducing government borrowing) and to achieve positive real interest rates to raise domestic savings. By 1985 interest rates had reached 20 per cent.

Cocoa prices were to be raised rapidly in real as well as nominal terms consistent with raising the net government revenue, because with massive devaluation, domestic prices and Cocoa Board costs would grow less rapidly than Cedi receipts. Additional foreign resources were to be mobilised from the Fund, Bank and bilaterals to finance additional imports, service existing debt and reduce arrears.

Liberalisation included ending almost all price controls (which were virtually totally ineffective) and - except for cocoa, shea nuts and palm oil - all ceiling agricultural purchase prices (which affected a negligible proportion of output in 1983). It also included no-questions-asked licensing of 'no forex' imports to capture the proceeds of outward smuggling and remittances from Ghanaians abroad. Import licensing, except for 'no forex' imports, was to be retained and made more efficient by systematic prioritisation.

Inflation was to be reduced sharply from the 50 per cent to 116 per cent rates which had characterised the late 1970s and early 1980s (albeit the 1982 rate had been 22 per cent). This was seen as possible because for most transactions prices were related to the parallel exchange rate.

\section{Results 1983-86 - The Programme Produces}

The programme's results were mixed but in its own terms basically satisfactory. Price increases rose to 122 per cent in 1983 ( 145 per cent food and 100 per cent non-food) but fell to 40 per cent in 1984 (11 per cent food and 69 per cent non-food) and 12 per cent in 1985 ( -11 per cent food and 50 per cent non-food) before rising to 23 per cent (about 15 and 30 per cent) in 1986. The nature of the price change pattern bears out that most prices as of 1983 had been closer to the parallel than the official exchange rate. However, it also indicates that a substantial portion (slightly over half) of 1983's accelerated inflation related to primarily weather induced food price rises and the bulk of the subsquent fall to weather related food price stabilisation.

Money supply increases were low. Government bank borrowing requirements fell. Enterprise credit demand remained low and banks began to refuse savings and time deposits, creating a somewhat artificial stability. By the second half of 1986 the liquidity problem had become acute. Banks were unable to extend enough credit or to mobilise enough currency for all viable enterprises to meet the conditions of the forex auction. 
The basic reason was the artificial curtailment of deposit (especially interest bearing deposit) levels.

GDProse 7.6 per cent in $1984,5.3$ per cent in 1985 and 5.6 per cent in 1986 - the first time per capita GDP had risen in three consecutive years since the 1950s. This growth was fairly widely distributed sectorally, albeit the high 1984 level relates in large part to weather related food crop harvest recovery. Exports fell sharply from $\$ 641 \mathrm{mn}$ in 1982 (and $\$ 1,104 \mathrm{mn}$ in 1980 ) to $\$ 441$ in 1983 , partly on volume decline related to weather and continuing infrastructure deterioration, and partly to price changes. The 1984 recovery to $\$ 566 \mathrm{mn}$ was dominated by favourable price changes, but those of 1985 to $\$ 632 \mathrm{mn}$ and 1986 to $\$ 773 \mathrm{mn}$ did reflect substantial output increases.

Public Services provision was badly hit by budgetary curtailment in 1983, as was public infrastructural investment. The ratio of budgetary spending to GDP fell to about 6.5 per cent $(5.5$ per cent recurrent and 1 per cent capital) and of revenue to 5.4 per cent. Further, the control method used of centralised, specific releases of funds for a wide range of items, while effective in curtailing expenditure, also curtails its efficiency. The overemployment/underemployment problem has yet to be tackled squarely. In the most overstaffed parastatal - the Cocoa Board employment at 89,000 to 110,000 (depending on coverage) could sensibly be cut not by 16,000 as achieved but to 16,000 (or perhaps 25,000 including certain related activities). To do so is critical to raising the growers' share in export proceeds without creating fiscal havoc. But such cuts are only possible if replanting and field staff laid off can be allocated replanted - or replantable - areas and assisted in becoming cocoa (or other crop) farmers.

The need to raise - not lower - the Budget/GDP ratio is now recognised, and indeed it has recovered to about 12 per cent ( 9 per cent recurrent, 3 per cent capital) on expenditure and 9 per cent on revenue side, with rehabilitation programmes for education and health begun. Revenue raising priorities, however, appear odd, as well as raising problems for the access of poor people and vulnerable groups. A remarkable number of low unit value, high administrative cost fees are being introduced, but sales and excise taxes, with few exceptions, remain derisory ( 1.5 per cent on schnapps, as a proportion of retail price) partly at least because old specific rates have been raised rather than converted to ad valorem scales at plausible levels.

The priorities for fixed capital formation are now rehabilitation and bottleneck breaking, albeit some project priorities appear odd - e.g. a low traffic new highway from Accra to the Ivory Coast border while the main north highway is omitted, despite finance from IDA secured in 1987. However, GFCF's absolute level appears dangerously low when compared to plausible depreciation estimates. Net fixed capital formation was 0.5 per cent in 1982 on what was even then a rather low depreciation estimate. It has risen to 5.4 per cent in 1985 largely because the estimated depreciation rate has been halved, otherwise it would be 2.0 per cent. Indeed, on depreciation/ capital stock procedures comparable to those used in a study of Zimbabwe it is negative. The domestic savings rate remains low - perhaps 6 per cent gross in 1985 and 8 per cent in 1986 but virtually negative at net level. Still, gross investment is rising in real terms and is probably given more careful and articulated attention than at any time since the early 1920 s.

\section{No time for Triumphalism: Problems and Problematics}

Several problems without clear answers remain and as a result - the sustainability of the programme remains problematic. To date Ghana's luck since 1983 has been good (early cocoa price rise, return of good weather, oil price slump). 1987 has been much more mixed (cocoa price fall, poor weather, partial oil price snapback) which suggests both greater external balance and food supply strains - both tending to push up inflation and to hold down growth.

Cocoa is a key problem. Official purchases by $1990 \mathrm{can}$ probably be pushed over 300,000 tonnes as a result of more smuggling clawed back, better input supply, initial payoff from replanting and new planting. But with Malaysia's growth from nowhere in 1980 to nearly 100,000 tonnes now, and to over 200,000 by 1990 (on trees already planted), Nigeria's export recovery, Ivory Coast's continued expansion, what will happen to the price? By 1990 cocoa export earnings at 300-325,000 tonnes could be below 1986 at 225,000 tonnes. Further, if the world price falls, the 30 per cent grower, 35 per cent Cocoa Board, 35 per cent Treasury split of proceeds will not provide adequate incentives. To date only the edges of the monstrous overemployment (equivalent to the private sector or all other parastatals) and cost (including transport) excesses of the Cocoa Board have been chipped at; large revenue cuts are hardly what the Treasury needs.

Food prices stand at 70 per cent of a 1977 base of 100 (compared to cost of living), probably the lowest index since the end of the $1950 \mathrm{~s}$. What impact will this have on output? To the early 1990 s the government projects 4 per cent annual growth and the World Bank 2 per cent against population growth of about 3 per cent. Neither estimate seems firmly based or to deal explicitly with droughts. Their divergence is crucial. Two per cent growth, more likely on the past record and 1986 prices, threatens economic, social and political stability. Four per cent would help consolidate it. This problem relates to the simple fact that in practice there is no coherent agricultural policy, and the ministry appears 
to have neither the financial resources, the data, the personnel nor the first hand contact with peasants to create one.

Labour and wages are a potential time-bomb. Ghana's TUC has helped instal - and tear down - every previous government. Now, despite a 1983-87 doubling of real wages (admittedly together with allowances still amounting to only half of a poor urban household's actual consumption basket - see e.g. Table 4), the TUC is openly hostile to and obstructive of the PNDC.

External finance is barely adequate - it will not cover any sudden shock (including a year's fall in Consultative Group pledges). Because of past soft loan gaps, debt service has risen to over 60 per cent of gross loan and grant inflows. Any balancing to 1990 (without hazardous use of hard finance) depends on the IMF substituting Structural Adjustment Facilities for repurchases falling due under past 1983 standbys. Thus any breach of a performance (trigger) clause could bring down the whole external finance structure.

Ghana is suffering from adjustment fatigue - five years' hard slog leaves many people and officials drained. But relaxation would not be safe - indeed the 1987-89 movement to full Open General Licence, 20 to 30 per cent uniform tariffs, a revised tax system and full parastatal reform could well prove harder to articulate and to manage than previous stages. If any of the problem areas cited above goes seriously wrong, there will be a full blown crisis which the very fragile economic and social recovery is hardly yet in a position to face.

This is not to say Ghana's programme is doomed. Far from it: its fragility is less than in any previous year. But the creeping conditionality toward full liberalisation from the Bank, the weaknesses of the real economy and the growing adjustment fatigue do mean that triumphal march music is still dangerously premature.

\section{Where Human Conditions Decay: Limitations of Success}

Per capita GDP in Ghana is at best two thirds what it was in 1960. The 1960-1970s advance in human conditions indicators (Table 3 ) had been crucially reversed through 1983 and, at best, has held its own except for malnutrition and conceivably the per cent in absolute poverty since. In 1986 with over five per cent real growth, per capita consumption fell three per cent apparently from demand overkill and lower real cash incomes for food selling peasants. The government health system (excluding the related Christian Health Association of Ghana) saw its real output plunge 50 per cent from 1979 through 1983; the education system is barely avoiding collapse; the rural water system has no assured capacity for maintenance.

Assuming that development is about, for and by people, and that imbalances between basic needs and the real incomes and access to services of the poor matter, that is a disastrous record. At the end of four years of stabilisation and three of rapid growth it is an indictment of Ghana's stabilisation strategy as at best integrally incomplete and at worst focused solely on macroeconomic restoration while people continued to decay.

This is emphatically not to argue that the severe decline in human conditions has been caused by the stabilisation programme. 1966-1981 (especially 197381) economic policy and non-policy must bear primary responsibility, and external shocks (not least the 1981-83 drought) secondary. Continuation of the 1979-81 drift or even the 1982 stabilisation without international support strategy would not have meant poor Ghanaians were less poor today - quite the contraty.

Nor has the programme as implemented harmed them by what it did, except for attempts in 1983-84 to restore fiscal balance by cutting real recurrent spending. More poor and vulnerable people have been made less poor and/or vulnerable since 1983 than the reverse. But that defence is not good enough. The absence of integrating human imbalance stabilisation into the programme's core strategy was - and to a large extent remains - a basic flaw.

Basic health, education and water sources raise productivity now and in the future. The sick, illiterate and poor cannot work long, hard, or productively. The failure to secure funds to restore the main highway to the north until 1987 has disadvantaged both that trio of poor regions and their poor people, and limited production recovery. So have agricultural, urban and public works strategies that failed to identify ways to enable poor people to produce more and to utilise Ghana's one abundant factor of production - labour - more fully.

It would not be fair to blame primarily the Fund or the Bank for this - especially from 1985 onward. The Bank may have treated health, education, the highway to the north and labour intensive public works as add ons - but it has moved to backing them firmly, which some observers would argue is more than could be said until 1987 of the Ghanaian ministries of Finance and Agriculture. The PNDC leadership has not been fully agreed on priorities and sequencies. Only in April 1987 did Ghana take a substantial production and productivity package by and for the poor to the Consultative Group, and even now the idea that adjust ment with a human face is about productive and allocational efficiency is far from fully integrated into macroeconomic programming. 


\section{Where Now? What Chance?}

For the PNDC, success of the programme is vital to its survival and to its attempt to recreate a participatory, democratic political process. For the majority of Ghanaians success is crucial to any alleviation from misery. Indeed for more than a few the stark meaning of failure would be seen in rising infant mortality and falling life expectancy. The West African proverb applies - give a rich man less food and he will grow thin; give a poor man less food and he will die.
For the Fund and the Bank, Ghana matters beyond the finance they have sunk in it from 1983 on (approaching $\$ 1,000 \mathrm{mn}$ at commitment level). If the longest running, arguably successful stabilisation/ adjustment programme collapses, their credibility in sub-Saharan Africa is likely to fall with it.

Despite the limitations to date and the problematics for the future, that necessity of continued and broadened success may help win the struggle toward it. Too many people and institutions (and not just in Ghana) have too much riding on it to accept failure

Table 1

Average Growth Rates Key Economic Indicators 1965-83 (per cent)

\begin{tabular}{|c|c|c|}
\hline Item & $1965-73$ & 1973-83 \\
\hline 1. Population ${ }^{\mathrm{a}}$ & 2.2 & 3.1 \\
\hline \multicolumn{3}{|l|}{ 2. Domestic production ${ }^{\mathrm{a}}$} \\
\hline (a) GDP & 3.4 & -1.3 \\
\hline (b) GDP per capita & 1.2 & -4.4 \\
\hline (c) Agriculture & 4.5 & 0.0 \\
\hline (d) Industry & 4.3 & -7.0 \\
\hline (e) Services & 1.1 & -0.3 \\
\hline \multicolumn{3}{|l|}{ 3. Merchandise trade } \\
\hline (a) Exports ${ }^{\mathrm{a}}$ & 3.5 & -6.4 \\
\hline (b) Imports ${ }^{a}$ & -3.3 & -8.0 \\
\hline (c) Terms of trade & - & -6.5 \\
\hline \multicolumn{3}{|l|}{ 4. Cocoa production ${ }^{b}$} \\
\hline \multicolumn{3}{|l|}{ 5. Food sector } \\
\hline (a) Food production ${ }^{c}$ & 2.0 & -2.7 \\
\hline (b) Food production per capita ${ }^{c}$ & -0.3 & -5.9 \\
\hline (c) Calorie availability per capita ${ }^{c}$ & 1.3 & -3.9 \\
\hline (i) from cereals & 3.8 & -3.3 \\
\hline (ii) from roots and tubers & -2.0 & -1.8 \\
\hline (d) Protein availability per capita ${ }^{\mathrm{c}}$ & 4.1 & -4.0 \\
\hline \multicolumn{3}{|l|}{ 6. Inflation } \\
\hline (a) Consumer prices & $6.3^{\mathrm{d}}$ & $49.9^{\mathrm{e}}$ \\
\hline (b) Food (local and imported) prices & $6.6^{\mathrm{d}}$ & $53.2^{\mathrm{e}}$ \\
\hline (c) Non-food prices & $5.8^{\mathrm{d}}$ & $46.5^{\mathrm{e}}$ \\
\hline
\end{tabular}

Notes: ${ }^{a}$ World Bank, 1985.

${ }^{\text {b }}$ Based on data provided by Ghana Cocoa Board, 1986.

${ }^{\circ}$ FAO and FAO computer print-outs, 1986.

${ }^{d}$ Based on data in Bequele, 1980, Appendix Table 7 with the weights for local and imported food $(0.5207$ and 0.0295$)$ from the World Bank.

' Based on data from Ghana Central Bureau of Statistics.

Source: Adapted from 1986 ILO Working Paper by T. Tabatabai. 
without a last ditch fight. Ghana's self confidence is growing, as is global confidence in her. Every year of success (probably every year of avoiding failure) strengthens the economy, the civil society, the chances of riding out serious negative shocks, when they come (as they will).

If Zambia over 1976-87 is evidence of how little a decade of stabilisation can produce, Ghana is evidence that something can be won, even after a decade and a half of decline. It may yet join Zimbabwe and Tanzania in demonstrating that the provision of services to poor people can be built into the core of a stabilisation/adjustment programme. The Black Star is no longer setting, the battle to sustain its second rising is one in which the Fund, the Bank and the PNDC have all made errors but have - to date managed to work together without major antagonistic contradictions at the operational level. If six more years (1988-93) of large soft resource injections can be secured, improvements in human conditions made integral to the programme, massive shock avoided (or financed) - then four to five per cent growth and steady improvement in human condition indicators will be sustainable and largely self-sustaining, humanly, socially and politically, as well as macroeconomically.

Table 2

Major Economic and Financial Indicators 1984-89

$\begin{array}{cccccc}\text { (Provisional) } & & & \\ \text { Actual } & \text { Estimates } & \text { Target } & & \text { Projections } \\ 1984 & 1985 & 1986 & 1986 & 1987 & 1988\end{array}$

1989

Growth rates

GDP

GDP deflator

Percent of market price GDP

National accounts

Consumption

Investment

Private

Budgetary capital expenditures

National savings

Public

Private

Of which: foreign transfers

Foreign savings

Central government budget

Total revenues

Total expenditure

Recurrent

Capital

Special efficiency

Overall deficit

Balance of payments

Exports of GNFS

Imports of GNFS

Resource balance

Current account balance

Overall balance

Broad money (M2)

COL
$8.6 \%$

$35.3 \%$

\section{$5.1 \%$}

$31.2 \%$

$5.3 \%$
$30.2 \%$

$5.5 \%$
$18.2 \%$

$5.0 \%$
$18.0 \%$

$5.3 \%$

$12.5 \%$

$5.3 \%$

$7.5 \%$

$\begin{array}{rrrr}95.1 \% & 95.7 \% & 92.3 \% & 95 \% \\ 7.6 \% & 7.3 \% & 10.3 \% & 14 \% \\ 4.0 \% & 3.4 \% & 4.4 \% & 5 \% \\ 3.6 \% & 3.8 \% & 5.9 \% & 9 \% \\ 4.7 \% & 3.1 \% & 6.6 \% & 6 \% \\ -0.4 \% & 0.1 \% & 1.7 \% & 2 \% \\ 5.1 \% & 3.0 \% & 4.8 \% & 4 \% \\ 1.0 \% & 0.5 \% & 0.9 \% & 1 \% \\ 2.8 \% & 4.2 \% & 3.7 \% & 7 \%\end{array}$

\section{$89.8 \%$}

$17.1 \%$

$7.9 \%$

$9.2 \%$

$8.5 \%$

$3.2 \%$

$5.3 \%$

$1.3 \%$

$8.6 \%$

$\begin{array}{rr}8.0 \% & 10.4 \% \\ 11.8 \% & 14.1 \% \\ 8.4 \% & 10.3 \% \\ 3.4 \% & 3.8 \% \\ 0.0 \% & 0.0 \% \\ 3.8 \% & 3.8 \%\end{array}$

$13.6 \%$
$17.8 \%$
$11.9 \%$
$5.9 \%$
$0.0 \%$
$4.1 \%$

$12 \%$
$20 \%$
$11 \%$
$6 \%$
$3 \%$
$8 \%$

$16.1 \%$

$22.8 \%$

$12.9 \%$

$9.2 \%$

$0.7 \%$

$6.6 \%$

\section{$16.2 \%$}

$23.6 \%$

$12.7 \%$

$9.9 \%$

$0.9 \%$

$7.4 \%$

$16.5 \%$

$24.4 \%$

$12.9 \%$

$10.8 \%$

$0.6 \%$

$7.9 \%$

$\begin{array}{rrrr}8.0 \% & 9.9 \% & 15.8 \% & 14 \% \\ -10.7 \% & -12.9 \% & -18.5 \% & -20 \% \\ -2.7 \% & -3.0 \% & -2.6 \% & -6 \% \\ -2.8 \% & -4.2 \% & -3.7 \% & -8 \% \\ -1.6 \% & -1.7 \% & -1.1 \% & +2 \%\end{array}$

$21.7 \%$
$-28.6 \%$
$-7.0 \%$
$-8.6 \%$
$2.8 \%$

$22.2 \%$

$-30.0 \%$

$-7.7 \%$

$-8.8 \%$

$3.0 \%$

$22.7 \%$

$-30.5 \%$

$-7.8 \%$

$-7.9 \%$

$2.5 \%$

$$
15
$$

12

16

15

18

20

22

Source: Adapted from Government of Ghana 1987 Economic Recovery Programme Presentation to Consultative Group 


\begin{tabular}{|c|c|c|c|c|c|}
\hline & 1960 & $\begin{array}{c}\text { Ghana } \\
1970\end{array}$ & $\begin{array}{l}\text { Late } \\
1970 \text { s }\end{array}$ & $1980 \mathrm{~s}$ & $\begin{array}{c}\text { Low Income sub } \\
\text { Saharan Africa } \\
1982\end{array}$ \\
\hline 1. Average life expectancy at birth & 45 & 49 & 55 & 53 & 48 \\
\hline 2. Infant mortality rate & 132 & 107 & 86 & $107-120$ & 118 \\
\hline 3. Child death rate & 27 & 21 & 15 & $25-30$ & 24 \\
\hline 4. Access to health facility ${ }^{b}$ & - & - & - & 30 & 45 \\
\hline $\begin{array}{l}\text { 5. Public health facility visits } \\
\text { per person per year }\end{array}$ & - & - & 0.7 & 0.4 & $2^{f}$ \\
\hline 6. Health budget as $\%$ of GDP & - & 1.2 & - & 0.26 & 0.95 \\
\hline $\begin{array}{l}\text { 7. Access to pure water } \\
\text { Rural } \\
\text { Urban } \\
\text { Total }\end{array}$ & $\overline{-}$ & $\begin{array}{l}14 \\
86 \\
35\end{array}$ & $\begin{array}{l}14 \\
86 \\
35\end{array}$ & $\begin{array}{l}48 \\
75 \\
60\end{array}$ & $\begin{array}{l}14 \\
62 \\
22\end{array}$ \\
\hline $\begin{array}{l}\text { 8. Access to excreta disposal } \\
\text { Rural } \\
\text { Urban } \\
\text { Total }\end{array}$ & $\overline{-}$ & $\begin{array}{l}40 \\
92 \\
55\end{array}$ & $\begin{array}{l}40 \\
95 \\
56\end{array}$ & $\begin{array}{l}30 \\
65 \\
44\end{array}$ & $\begin{array}{l}25 \\
69 \\
32\end{array}$ \\
\hline $\begin{array}{l}\text { 9. Average calorie availability } \\
\text { as a } \% \text { of requirements }\end{array}$ & 92 & 97 & 88 & 68 & 91 \\
\hline $\begin{array}{l}\text { 10. Child malnutrition } \\
\text { (moderate/severe) }\end{array}$ & - & - & 36 & $50-55$ & 40 \\
\hline $\begin{array}{l}\text { 11. Primary education enrolment } \\
\text { ratio }^{\mathrm{e}}\end{array}$ & $38(46)$ & $64(75)$ & $69(80)$ & $-(80)$ & $69(-)$ \\
\hline 12. Adult literacy & 27 & 30 & - & $35-45$ & 44 \\
\hline 13. Education budget as $\%$ of GDP & - & 3.9 & - & 0.85 & 2.81 \\
\hline $\begin{array}{l}\text { 14. Proportion of population below } \\
\text { absolute poverty line } \\
\text { Rural }\end{array}$ & - & - & $\begin{array}{l}60-65 \\
30-35\end{array}$ & $\begin{array}{l}67-1 / 2- \\
72-1 / 2 \\
45-50\end{array}$ & $\begin{array}{l}65 \\
35\end{array}$ \\
\hline
\end{tabular}

Principal Sources: World Bank, Comparative Analysis and Data Division, Economic Analysis and Projections Department (June 1984), World Development Report 1985; UNICEF, Statistics on Children in UNICEF Assisted Countries (April 1985); UNICEF Ghana: Situation Analysis of Women and Children (July 1984).

Notes: a 1960 data refer to a year between 1959 and 1961; 1970 between 1969 and 1971; late 1970s between 1975 and 1980; 1980s to 1982,1984 or 1985.

${ }^{\mathrm{b}}$ Defined in terms of location within a 5 kilometre radius. May overstate for urban population when facilities available are small to serve the entire population nominally within reach of them.

c 1970 and late 1970s urban figures may be overstated by failing to relate number of water points to population.

d 1970 and 1978 figures for urban and possibly rural areas overstate by failing to relate number of drop-holes to supposed user population.

e Adjusted for length of primary cycle. () are unadjusted figures. Because of the primary/middle school division Ghana has a shorter primary cycle than most SSA countries.

$\mathrm{f}$ Estimate made by author on basis of fragmentary data. 


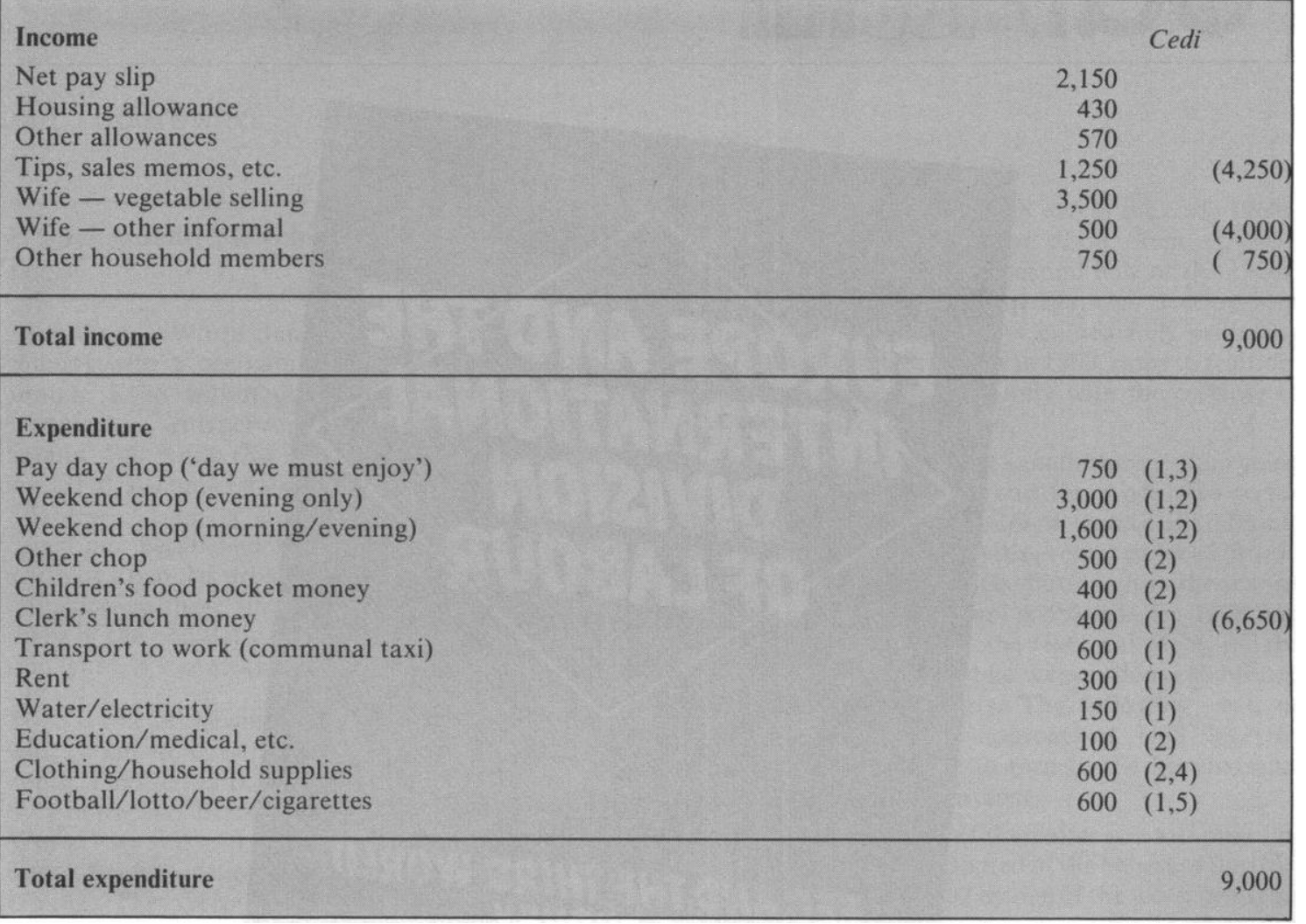

Notes:

(1) Paid by clerk or mixed.

(2) Dominantly paid by wife.

(3) Chicken Cedi 450; other Cedi 300.

(4) Implicitly $1 / 2$ shirt, 1 metre cloth, 2 cakes soap a month.

(5) Implicitly 3 bottles beer, 40 cigarettes, 1 football match, 2 Lotto forms a month.

Source: Adapted From West Africa 27-I-86 and fragmentary data on expenditure, income patterns. Estimate roughly squares with World Bank quasi survey suggesting wage earning household expenditure four times wages and over two thirds on food. Raises doubts as to appropriateness 50 per cent food weight in Cost of Living Index. 